\title{
Motivations for innovation in the built environment: new directions for research
}

Article

Accepted Version

Whyte, J. and Sexton, M. (2011) Motivations for innovation in the built environment: new directions for research. Building Research and Information, 39 (5). pp. 473-482. ISSN 14664321 doi: https://doi.org/10.1080/09613218.2011.592268 Available at https://centaur.reading.ac.uk/21699/

It is advisable to refer to the publisher's version if you intend to cite from the work. See Guidance on citing.

To link to this article DOI: http://dx.doi.org/10.1080/09613218.2011.592268

Publisher: Taylor \& Francis

All outputs in CentAUR are protected by Intellectual Property Rights law, including copyright law. Copyright and IPR is retained by the creators or other copyright holders. Terms and conditions for use of this material are defined in the End User Agreement.

\section{$\underline{\text { www.reading.ac.uk/centaur }}$}

\section{CentAUR}

Central Archive at the University of Reading

Reading's research outputs online 
Motivations for Innovation in the Built Environment:

New Directions for Research

Jennifer Whyte and Martin Sexton

School of Construction Management and Engineering,

University of Reading, Whiteknights, RG6 6AW, UK

Emails: j.whyte@reading.ac.uk; m.g.sexton@reading.ac.uk

Uncorrected author copy, please cite the published version:

Whyte, J. and Sexton, M. (2011)

Motivations for innovation in the built environment: New directions for research, Building Research and 
Information, Vol. 39, Issue 5, pp. 473-482.

http://dx.doi.org/10.1080/09613218.2011.592268

The final, definitive version of this paper has been published in Building Research and Information, $39 / 05,2011$

by Taylor and Francis Ltd, All rights reserved. (C) This is the accepted version, posted by the first author on the

University of Reading website under the terms of the contributor agreement. Please cite the published version

and refer to it for pages, etc. 
Motivations for Innovation in the Built Environment:

New Directions for Research

Innovation in the built environment involves multiple actors with diverse motivations. Policy makers find it

difficult to promote changes that require cooperation from these numerous and dispersed actors and to align

their sometimes divergent interests. Established research traditions on the economics and management of

innovation pay only limited attention to stakeholder choices, engagement and motivation. This paper reviews

the insights that emerge as research in these traditions comes into contact with work on innovation from

sociological and political perspectives. It contributes by highlighting growing areas of research on user

involvement in complex innovation, collective action, distributed innovation and transition management. To

differing extents, these provide approaches to incorporate the motivations of different actors into our theoretical

understanding. They indicate new directions for research that promise to enrich understanding of innovation.

Keywords: innovation theory, built environment, stakeholders, design, institutions, networks, transitions.

Introduction 
How can innovation theory inform the transformation of the built environment? The question is pertinent as

there is substantial pressure for a radical transformation of the way that buildings and infrastructure are managed

across their life-cycle to address enhanced social aspirations as well as the challenges of changing climate,

demographic growth, financial constraints and aging infrastructure. Governments recognize the central role that

construction industries have in creating and sustaining built environments which stimulate quality of life and

wealth generation. They further recognize that construction industries have a pivot part to play in the large

transformations required to bring about low-carbon built environments. The UK government, for example, has

set targets for a reduction in CO2 emissions of $80 \%$ by 2050 compared to 1990 levels (HM Government, 2008).

Yet policy makers have found it difficult to promote changes that require cooperation from numerous dispersed

actors with divergent interests. Over many years, research on the economics of innovation has had a significant

impact on policy, with the Organisation for Economic Co-operation and Development (OECD) developing a

standard way of measuring industrial research and development (R\&D) across the member countries (OECD 
1963). The theoretical approach is informed by an understanding that technological change is an endogenous

feature of economic systems and, hence, that technological change can be induced by policies that incentivise

certain technological trajectories. Further, this school of thought has been guided by a perception that industrial

innovation is science driven and conducted in large multi-divisional firms. Yet weaknesses in taking this

approach to innovation in complex settings such as the built environment, include a poor conceptualization of

distributed design and production activities (Gann 2000); a focus on research, development and manufacturing

within large multi-divisional firms (Hobday 1998); and a neglect of the negative, as well as positive, effects of

technological changes across wider institutional landscapes (Edgerton 2007). To this list, could be added a

narrow understanding of value, with the focus of policy debates on economic value (and related measures at

firm-level) rather than broader societal or environmental value. Underlying these weaknesses is the lack of

attention to the diversity of actors involved, these actors. choices and motivations, and the processes involved in

taking up and using new technologies across heterogeneous networks of practice.

This paper contributes by articulating the insights that emerge as established research traditions on the

economics and management of innovation come into contact with work on innovation from sociological and

political perspectives. The next section reviews the insights of the research traditions on economics and

management of innovation, both in relation to government policy, and firm-level innovation, and identifies its

limitations in addressing stakeholder engagement in the transformation of the built environment. The following 
section then discusses influence of sociological and political perspectives on innovation, and the new work at

the interfaces of these traditions that explores user involvement in complex innovation, collective action,

distributed innovation and technology transitions. The final section outlines the implications for research.

Early work on the economics and management of innovation and its critique

The narrative of progress underpins much of the early work in the economics of innovation tradition (Edgerton

2007). The key insight in this literature is that technological change is intrinsic to the economic system

(Freeman 1982). Rather than an external variable it becomes seen as a force that acts from within a capitalist

economy. The research tradition draws on earlier work by Schumpeter (1942), who speculates that:

"The opening up of new markets, foreign or domestic, and the organizational development from the craft shop and factory to such concerns as US Steel illustrate the same process of industrial mutation

if I may use the biological term - that incessantly revolutionizes the economic structure from within, incessantly destroying the old one, incessantly creating a new one. This process of Creative Destruction 
is the essential fact about capitalism. It is what capitalism consists in and what every capitalist concern

has got to live in.. (p83, italics in original)

In the late 20th century, innovation was studied across sectoral systems of innovation (Pavitt 1984) and in

national (and later regional) systems of innovation (Lundvall 1992). In this work, some sectors are seen as

„high-tech. - new industries in which a few general purpose technologies that drive economic development are

created, others, such as construction, became characterised as „low-tech. sectors (von Tunzelmann and Acha

2005), mature industries that obtaining new technology mainly from outside their sector. As a consequence, in

such a theoretical approach, innovation is given a therapeutic role in an industry that is assumed to be sick or

backwardi.

The „post-Schumpeterian literature. continues to retain family resemblances and shared outputs (e.g. see

Fagerberg, Mowery et al. 2005) and there is a focus on both government policy and also firm-level innovation,

particularly within the large multi-divisional manufacturing firm. The management of innovation has become

codified in standard texts (e.g. Tidd, Bessant et al. 2005; Dodgson, Gann et al. 2008), that describe the various

types of innovation (e.g. product and process innovation), degrees of novelty (incremental to radical) and their

significance (systemic, component level etc); discussing management of innovation at a firm-level. At a firm

level, the interest in how firms profit from innovation (Teece 1986), where such discussion of incentives and 
innovation becomes concerned with intellectual property (Scotchmer 2004); licensing; and ownership of

complementary assets.

At a policy level, the narrative of progress has led to a neglect of the negative effects of technological changes

across wider institutional landscapes. Hence innovation has been seen a positive for economic growth, with little

consideration of the directions of innovation and questions of technological choice. This is clearly articulated in

Freeman.s (1982) description of long-waves, reproduced in Dodgson (2000) and more recently in Hargroves

and Smith (2005), and summarised in Figure 1. The long-wave idea has its roots in the Kondratiev (1925)

proposition of 50-70 year waves of epoch-making clusters of innovation.

While this gives a broad historical framework on which to "hang. narratives of change, the robustness of the

long-wave proposition has been attacked across a number of fronts. In articulating the institutional context for

relationship between the economic cycle and the innovation cycle, and seeking to extend the theory towards a

more institutional understanding, Perez (1985: 442) argues that, "Kondratiev's long waves are not a strictly

economic phenomenon, but rather the manifestation, measurable in economic terms, of the harmonious or 
disharmonious behaviour of the total socioeconomic and institutional system (on the national and international

levels)." The compression of such waves to shorter and shorter periods is also being witnessed, along with the

increasingly distributed nature innovation clusters which cross technology and sector boundaries.

$<<$ Insert Figure 1 here >>

Among the critics, Edgerton is explicit in his critique of the classic accounts of innovation, arguing that "such

accounts, for all that they reflect what we think we know, are not as well founded as might be supposed"

(Edgerton 2007: p. 3). In contrast he argues for a use-based history of technology that recognises that there are

always alternatives: "there are multiple military technologies, means of generating energy, powering a motor

car, storing and manipulating information, cutting metal and roofing a building" (Edgerton 2007: xiii). Instead

of privileging the new, this history should, he argues focus on technologies-in-use, hence highlighting the

multiple hybrid forms that arise; the multiple uses and the potential growth in significance of technologies in

use, long after their invention, when they have ceased to be novel. This reframing brings production and

maintenance into view, it brings into view the connections between technologies and warfare; and potentially,

although not explicitly in Edgerton.s work, between technologies and environmental degradation. 
Emerging areas

In the past five years, innovation management, like other areas of management, has begun to come into contact

with, draw on and contribute to other streams of research on innovation and technology, which developed

separately from sociology and political perspectives. These include traditions of work in organization theory; the

sociology of technology (Pinch and Bijker 1987; Bijker 1995), consumption (Shove, Watson et al. 2007);

diffusion of innovation (Rogers 2003 [1962]); institutional innovation (Hargadon and Sutton 1997; Van de Ven,

Polley et al. 1999) and the historical use of technology (Hughes 1983; Hughes 2005; Edgerton 2007). At the

interfaces between these traditions, new areas of research are developing around user involvement in complex

innovation, collective action; distributed innovation; and transition management. These new literatures,

developing out of the synthesis of different traditions, are characterised and compared with the traditional

studies of long waves and firm-level innovation in Table 1. 
$<<$ Insert Table 1 here $>>$

User involvement in complex innovation

Within the post-Schumpeterian tradition of innovation studies, later theoretical and empirical work reframes

innovation not as a deterministic, linear progression, but rather as a far more complex interaction between users,

producers and intermediaries located in (and shaping) an institutional context. An example is the work on

innovation in complex products and services (Hobday 1998), which has changed understanding of innovation

systems bringing into view the work of engineers (as well as scientists, who were seen as the main source of

innovation in the early linear models) and the role of project-based professional engineering firms. Such work

begins to draw attention to the diversity of actors and motivations involved in contexts such as the built

environment. For example Barrett and Sexton (2006) highlight how in small, project-based firms, the motivations for innovation are not growth, but instead often „to get past a survival mode of operating and to

achieve stability by satisfying clients.. In comparison with larger firms, owners plays a key role, the markets are

relatively niche and there is a lack of slack resources with innovations closely tied to operational activities.

Likewise, while the focus on intellectual property and shareholder value has led to a rather narrow conceptualisation of innovation, for example through patent analysis, some work within a wider economically

informed tradition is beginning to expand the field of view, for example by articulating the importance of

stakeholder engagement, not only to wider objectives, but also to shareholder value (Henisz, Dorobantu et al.

2010). 
There are a number of other emerging areas of research within this tradition, such as the work on users, with

ideas of co-construction of users and technology (Oudshoorn and Pinch 2003) and demand (McMeekin, Green

et al. 2002), democratising innovation (von Hippel 2005); and open innovation (Chesbrough 2003). The work

on users shifted the focus from hitherto inward-looking, linear models of innovation, to a perspective in which

firms look both inside and outside the firm for new knowledge to accelerate the flow of innovation and the

securing of both internal and external paths to market. The empirical research which the open innovation

perspective is grounded in, however, is from large, product-based manufacturing sectors. This work takes

innovation theory a long way since its articulation as an opaque „black box. which linked economic inputs and

outputs. Successful innovation requires purposeful, intricate interaction between institutional and organizational

field actors. However, important aspects of this more complex, nuanced understanding have not migrated

altogether successfully into policy; and there remain some intrinsic limitations in addressing stakeholder 
engagement. Hence the utility of open innovation, in its current form, to the project-based, productservice

characteristics of the construction sector is undecided.

Collective action: new developments in institutional innovation

Ideas from institutional theory are becoming mobilised by scholars interested in the production of the built

environment to understand conflicts (Mahalingam and Levitt 2007) and institutional exceptions (Orr and Scott

2008) on global building and infrastructure projects. This work draws attention to the regulatory (explicit,

formal rules which constrain or enable behaviour and regulate interactions): cognitive (rules which constitute the

nature of reality and the frames through which meaning or sense is made); and normative (rules which confer

values, norms, roles, expectations, duties, rights and responsibilities) mechanisms through which institutional

change occurs (Scott 2001), in the context of the built environment. While the findings of institutional

approaches to innovation resonate with other work, which has for example speculated on the role of regulation

as a factor in promoting energy efficiency in buildings (Gann, Wang et al. 1998; Sheffer and Levitt 2010), new

developments in institutional theory are providing a new vocabulary for discussing collective action.

Institutional theorists typically consider innovation at the level of the organizational field, an intermediate level

between organization and society (DiMaggio 1988; Greenwood, Suddaby et al. 2002). For example Vermeulen,

Büch et al. (2007) examine innovation within organizational fields through a study of the concrete industry in 
the Netherlands, articulating the roles of regulatory structures, professional associations and competitors in

market suppression. They see active resistance from professional associations and corporate actors inhibiting the

creation of a new market. Greenwood, Suddaby et al. acknowledge these potentially negative influences of

professional association but also show how they play a role in promoting and theorising change within a

professional field. In this work, legitimacy is seen as a strong motive for institutional action, and a commonly

used research strategy is to track the discourses that develop around new technologies (Munir and Phillips

2005), a strategy that has also been used in the construction management literature to highlight the rhetorical

strategies of innovation champions in justifying and legitimating the diffusion of innovations

(Leiringer and

Cardellino 2008).

The connections between institutions, innovations and industries have been discussed by Hargadon and Douglas

(2001) in the formation of new industries, such as those developed though Edison.s work.

Lounsbury,

Ventresca et al. (2003) synthesize work on institutions and social movements (Strang and Soule 1998) to show

how field frames impact development of the US recycling industry. Garud and Karnøe (2003)

describe the 
contrasting development of the wind turbine industries in the USA and Denmark. In some of this work the idea

of „institutional entrepreneur. has been used to describe how an actor conducts work to change institutions

(Garud, Jain et al. 2002; Lawrence and Phillips 2004; Maguire, Hardy et al. 2004; Dorado 2005; Munir and

Phillips 2005; Greenwood and Suddaby 2006; Perkmann and Spicer 2007; Battilana, Leca et al. 2009). This

literature addresses a general critique of institutional theory that it emphasises stability rather than change, but a

parallel critique that has been levelled at this literature is that it under-plays the embeddedness of actors within

their institutional contexts and the boundedness of their actions.

Extending this work, the idea of "collective action. is examined in recent work by institutional theorists

(Hargrave and Van de Ven 2006; Wijen and Ansari 2007), it shifts the focus from the individual entrepreneur

and focuses attention on how actors become mobilized around common issues (Ritvala and Salmi 2008), and

how institutions are changed through this more distributed work. Based on a review of institutional innovation

and social movements, Hargrave and Van de Ven describe a model of collective action as a

"dialectical theory

of change in which opposing actors in the organizational field frame issues, mobilize collective actions, and

engage in contested processes in order to achieve material improvement, be it technical or social" (Hargrave

and Van de Ven 2006: p.887). Wijen and Ansari likewise synthesize literatures in their interpretation of

collective action, bringing institutional theory into contact with regime theory, a tradition of work in international relations, to shift the focus toward the manipulation of power configurations; common-ground; 
bandwagons; incentive structures; ethical guidelines and implementation mechanisms.

Distributed innovation: Project-based firms and distributed networks of innovation

Sociology of technology perspectives have become used directly, and mediated through their discussion in the

management literatures, in the analysis of the built environment. Hence Schweber and Harty (2010) use a

language of networks, rather than fields, in examining the development of British and American reinforced

concrete industries from a sociology of technology perspective, highlighting how in the UK, groups remained in

their own circles with tenuous links; while in the USA there was a broader reconfiguration that involved

practices of patenting and licensing; and university-industry links as well as onsite practices.

This literature draws attention to the strange translations that occur as designers articulate and represent a

projected future in the present and use it to persuade and enrol others (Tryggestad, Georg et al. 2010). Here

technology development is constituted in essentially political terms, and the focus is on "the delegation of

interests on to technological artefacts and [...] the mobilization of actors and artefacts to constrain and limit 
the scope of negotiations over new technology implementation." (Harty 2008). Such insights are also percolating across the strategy and organization management literature, where actor network theory is being

explored to more fully interrogate key concepts such as „resources. in strategy (Steen 2010); to challenge the

idea of micro-foundations of strategy (Steen, Coopmans et al. 2006) and to describe the „action nets. that arise

(Czarniawska 2004).

The concept of „unbounded innovation. has been used to characterise situations in which technology

development spans organizational contexts (Harty 2005). Construction is seen as one such context, both in this

work, and in parallel descriptions of the "wakes. of innovation that propagate through project networks (Boland,

Lyytinen et al. 2007). These ideas are becoming more widely used within construction management as a means

of uncovering the mechanisms through which implementation occurs (Jacobsson and Linderoth 2010).

Transition management and multiple level perspectives of innovation

Policy-makers are becoming aware of the limitations of narrow economic view of innovation and are embracing

multiple level perspectives. These perspectives recognise development and link the myriad institutional,

managerial, economic and socio-technical aspects which, in part, have been introduced in this paper through a

review of the relevant literature. The multiple level perspective (MLP) is grounded in a systems approach. The

potential strengths of this approach are summarised by Edquist (1995: 186) as follows: (a) it is holistic, aiming 
to accommodate all of the important determinants of innovation; (b) it is interdisciplinary, drawing upon a range

of disciplines including economics, sociology and economic history; (c) it stresses interdependence, recognising

the role of external sources of innovation and inter-organisational networks; (d) it emphasises nonlinearity,

capturing the recursive, iterative and distributed nature of innovation; and (e) it emphasises institutional context,

with its regulatory, normative and coercive enabling and constraining structures and agencies. This systemic

approach has greatest continuity with the established economic and management literatures, but introduces some

important new considerations.

The systemic approach has been mobilised across a number of geographic, sector and technology dimensions. A

common trajectory for this work is a move towards more fine-grained, analytical understanding. Early work on

national innovation systems (Lundvall 1992; Nelson 1993) to identify the core set of institutions whose

interactions determine national innovation performance has been used in analysis of regional systems of

innovation (Piore and Sabel 1982; Casper 2007). The honing down on regions is fuelled by the argument that,

"the factors that the national innovation systems theory identifies as important, such as the institutional 
framework, the nature of inter-firm relationships, learning capability, R\&D intensity and innovation activity all

differ significantly across regions" (Oughton, Landabaso et al. 2002: p. 99). The use of system thinking in the

analysis of sectoral innovation systems (Malerba 2004) and technological innovation systems (Carlsson 1995)

has been similarly driven by a desire to better understand innovation dynamics across a wider variety of specific

settings.

These strands of complementary work have more recently begun to intertwine to form a multiple level

perspective (MLP) of innovation to understand and influence durable and complex socio-technical transitions.

The MLP is being applied, in particular, to the challenge of managing the system transition to sustainability

(Elzen, et al. 2004). In broad terms, the multiple level perspective (MLP) emerged from the early work of Kemp

(1994) and Schot et al., (1994) which brought together, economic studies of innovation, science and technology

studies and institutional considerations to understand the co-evolution processes that require multiple changes in

socio-technical systems. These processes made transparent and linked both the generation, selection and

diffusion of new technologies; user practices; and, the broader process of societal embedding of new

technologies in the form of, for example, regulations, markets, infrastructures and cultural symbols (Grin, et al.,

2010).

For the transformation towards zero-carbon to take place, new socio-technical regimes with powerful functions 
need to emerge around the new range of design and production solutions. These regimes, if they are to achieve

the position envisioned and dictated by policy and regulation, will need to be steered through transition

management processes (Geels 2004). More specifically it focuses attention on the ongoing engagement and

integration of stakeholders, creation and solidification of supply chains, standardisation of components and

articulation of practices and communication of shared goals and understandings.

Discussion and directions for further research

Policy makers seeking innovation in the built environment face high levels of uncertainty that create particular

issues. The type of problems they face have been described as „wicked problems. (Rittel and Webber 1984),

requiring "clumsy solutions. (Verweij, Douglas et al. 2006). Here there is a need to consider how policy

solutions create silence and voice for different stakeholders; and broad societal and environmental value

throughout their life-cycle. Policy-makers have particularly struggled to understand innovation in building and

infrastructure design, where work is distributed across global networks of manufacturing and use. Here, 
innovation policy continues to be based on understandings developed in the 20th century that contain

assumptions that undermine its potential to deliver change for the 21st century. This paper contributes to their

work by highlighting some new directions for research that examines the motivations of different actors to

understanding innovation in the built environment.

The studies of innovation in the built environment draw on and contribute to wider theoretical understanding

from economics, management and sociology. Different studies start out with different units of analysis, levels of

analysis, conceptualizations of the role of stakeholders and areas of study. As discussed above, and roughly

summarised in Table 1, these alternative conceptualisations accent different aspects of innovation. It is thus

important to continue to trace, compare and, where appropriate, bring together, these alternatives. Doing so

enable us to see both how the theory and practice of innovation in the built environment can be improved and

also, importantly, how studies of the built environment can make strong contributions to broader theoretical

understandings of the distributed, multi-actor nature of innovation that is observed in many contexts.

The different emphasis of the literatures discussed in this paper, summarised in Table 1, suggests a shift toward

a focus on the connections between evolving configurations of social and technical rather than simple changes

of technology. Within the emerging literatures there is an exploration of analyses at a „meso.-level that seeks to

trace connections between local and global practices. While long-wave theory focuses policy attention on the 
speed of industrial development, these emerging theories draw attention to stakeholders their choices and

motivations and the processes of taking up and using new technologies. Within the literature on management of

innovation within the firm, there is a growing understanding that the motivations of firms differ, e.g. from small

to large firms, and that the engagement of stakeholders outside the firm can contribute to shareholder value.

Sociological and political perspectives add a focus on the mechanisms involved in innovation across a diverse

range of actors.

The challenge that such literatures help to address is the mechanisms through which plans for change and

innovation become enacted in practice. This is relevant as a key challenge that policy makers face is to construct

documents that can shape future action, while avoiding what Clarke (1999) calls „fantasy documents.. Fantasy

documents rhetorically transform uncertainties into risks, making them seem manageable. Yet they fail, not only

because their end goals are abstract, but because they contain uncertainties that are unacknowledged. Hence:

"Some plans are highly instrumental, but others are little more than vague hopes for remote futures and

have virtually no known connection with human capacity or will." (Clarke 1999: p.16) 
The emerging literatures on user involvement in complex innovation, collective action, distributed innovation

and transition management suggest new starting points and directions for research on the changes that occur

across complex multi-stakeholder organizational environments. Though macro-level and firm-level analyses

remain important and are explored in the economics and management of innovation, within these emerging

literatures there is instead an exploration of analyses at a meso-level. This involves a shift toward a focus on the

connections between evolving configurations of social and technical rather than simple changes of technology.

Important work has considered social practices around the diffusion of discrete and relatively unmodifiable

technologies, such as new drugs in a medical setting, highlighting how social and cognitive boundaries arise

between different professions, which operate as separate communities of practice (Ferlie, Fitzgerald et al. 2005).

However the innovations considered in the emerging literatures, and those that concern scholars of the built

environment, are themselves in flux and are constituted as evolving configurations involving both social and

technical elements experienced through practices. The need for better theoretical understanding becomes all the

more pertinent, as our questions increasingly focus on understanding the broader value of innovation to multiple

stakeholders, rather than its value to shareholders and or intellectual property value in the short term.

References 
Barrett, P. and M. Sexton (2006). "Innovation in Small, Project-Based Construction Firms." British Journal of

Management 17(4): 331-346.

Battilana, J., B. Leca, et al. (2009). "How Actors Change Institutions: Towards a Theory of Institutional Entrepreneurship." The Academy of Management Annals 3: 65 - 107.

Bijker, W. E. (1995). Of Bicycles, Bakelites and Bulbs. Cambridge, MA, MIT Press.

Boland, R. J., K. Lyytinen, et al. (2007). "Wakes of Innovation in Project Networks: The Case of Digital 3-D

Representations in Architecture, Engineering, and Construction." Organization Science 18(4): 631647.

Carlsson, B. (1995). Technological systems and economic performance: the case of factory automation.

Dordrecht, Netherlands, Kluwer.

Casper, S. (2007). "How do technology clusters emerge and become sustainable? Social network formation and inter-firm mobility within thye San Diego biotechnology cluster." Research Policy 36: 438-455.

Chesbrough, H. (2003). Open Innovation: the New Imperative for Creating and Profiting from Technology.

Cambridge, M.A., Harvard Business School Press.

Clarke, L. B. (1999). Mission improbable: using fantasy documents to tame disaster. Chicago, University of

Chicago. 
Czarniawska, B. (2004). "On Time, Space, and Action Nets." Organization 11(6): 773-791.

DiMaggio, P. J. (1988). Constructing an organizational field as a professional project: U.S. art museums, 1920-

1940. The new institutionalism in organizational analysis. W. W. Powell and P. J. DiMaggio. Chicago, University of Chicago Press: 267-292.

Dodgson, M. (2000). The Management of Technological Innovation: An International and Strategic Approach.

Oxford, Oxford University Press.

Dodgson, M., D. M. Gann, et al. (2008). The Management of Technological Innovation: Strategy and Practice

Oxford, Oxford University Press.

Dorado, S. (2005). "Institutional entrepreneurship, partaking, and convening." Organization Studies 26(3): 383-

413. 
Edgerton, D. (2007). The Shock of the Old: Technology and Global History since 1900, Profile Books / Oxford

University Press.

Ferlie, E., L. Fitzgerald, et al. (2005). "The Nonspread of Innovations: The mediating role of professions."

Academy of Management Journal 48(1): 117-134.

Freeman, C. (1982). The Economics of Industrial Innovation. London, Frances Pinter (Publishers) Ltd.

Gann, D. M. (2000). Building Innovation: Complex constructs in a changing world. London, Thomas Telford.

Gann, D. M., Y. Wang, et al. (1998). "Do regulations encourage innovation? - the case of energy efficiency in

housing." Building Research \& Information 26(5): 280 - 296.

Garud, R., S. Jain, et al. (2002). "Institutional Entrepreneurship in the sponsorship of common technological

standards: the case of Sun Microsystems and Java." Academy of Management Journal 45(1): 196214.

Garud, R. and P. Karnøe (2003). "Bricolage versus breakthrough: Distributed and embedded agency in

technology entrepreneurship." Research Policy 32(2): 277-300.

Geels, F. W. (2004). "From sectoral systems of innovation to socio-technical systems: Insights about dynamics

and change from sociology and institutional theory." Research Policy 33(6-7): 897-920

Greenwood, R. and R. Suddaby (2006). "Institutional Entrepreneurship in Mature Fields: The Big Five 
Accounting Firms." Academy of Management Journal 49(1): 27-41.

Greenwood, R., R. Suddaby, et al. (2002). "Thoerizing change: The role of professional associations in the

transformation of institutional fields." Academy of Management Journal 45(1): 58-80.

Hargadon, A. and R. Sutton (1997). "Technology Brokering and Innovation in a Product Development Firm."

Administrative Science Quarterly 42(4): 716-749.

Hargadon, A. B. and Y. Douglas (2001). "When innovations meet institutions: Edison and the design of the

electric light." Administrative Science Quarterly 46(3): 476-501.

Hargrave, T. J. and A. H. Van de Ven (2006). "A Collective Action Model of Institutional Innovation." Academy of Management Review 31(4): 864-888.

Hargroves, K. and M. H. Smith (2005). The natural advantage of nations: business opportunities, innovation

and governance in the 21st century. London, Earthscan.

Harty, C. (2005). "Innovation in construction: a sociology of technology approach." Building Research and

Information 33(6): 512-522.

Harty, C. (2008). "Implementing innovation in construction: contexts, relative boundedness and actor-network theory." Construction Management and Economics 26(10): 1029 - 1041. 
Henisz, W. J., S. Dorobantu, et al. (2010). Spinning Gold: The Financial Returns to External Stakeholder

Engagement.

Hobday, M. (1998). "Product complexity, innovation and industrial organisation." Research Policy 26(6): 689-

710.

Hughes, T., P. (1983). Networks of Power: Electrification in Western Society, 1880-1930. Baltimore and

London, John Hopkins University Press.

Hughes, T., P. (2005). The human-built world: How to think about technology and culture. Chicago, University

of Chicago.

Jacobsson, M. and H. C. Linderoth (2010). "The influence of contextual elements, actors' frames of reference,

and technology on the adoption and use of ICT in construction projects: a Swedish case study." Construction Management and Economics 28(1): 13-23.

Lawrence, T. B. and N. Phillips (2004). "From Moby Dick to Free Willy : Macro-Cultural Discourse and Institutional Entrepreneurship in Emerging Institutional Fields." Organization 11(5): 689-711.

Leiringer, R. and P. Cardellino (2008). "Tales of the Expected: Investigating the Rhetorical Strategies of

Innovation Champions." Construction Management and Economics 26(10): 1043-1054.

Lounsbury, M., M. J. Ventresca, et al. (2003). "Social movements, field frames and industry emergence: a 
cultural-political perspective on US recycling " Socio-Economic Review 1(1): 71-104.

Lundvall, B. A., Ed. (1992). National Systems of Innovation. London, Pinter.

Maguire, S., C. Hardy, et al. (2004). "Institutional Entrepreneurship in Emerging Fields: HIV/AIDS Treatment

Advocacy in Canada " Academy of Management Journal 47(5): 657-679.

Mahalingam, A. and R. E. Levitt (2007). "Institutional Theory as a Framework for Analyzing Conflicts on

Global Projects." Journal of Construction Engineering and Management: 517-528.

Malerba, F., Ed. (2004). Sectoral system of innovation: concepts, issues and analyses of six major sectors in

Europe. Cambridge, Cambridge University Press.

McMeekin, A., K. Green, et al. (2002). Innovation by Demand: Interdisciplinary Approaches to the Study of

Demand and its Role in Innovation, . Manchester, Manchester University Press.

Munir, K. and N. Phillips (2005). "The birth of the Kodak moment: institutional entrepreneurship and the

adoption of new technologies." Organization Studies 26(11): 1665-1687.

Nelson, R., Ed. (1993). National innovation systems: a comparative analysis. Oxford, Oxford University Press.

OECD (1963). The Measurement of Scientific and Technical Activities: Proposed Standard Practice for 
Surveys of Research and Experimental Development (Frascati Manual). Paris, OECD.

Orr, R. J. and W. R. Scott (2008). "Institutional exceptions on global projects: a process model." Journal of

International Business Studies 39: 562-588.

Oudshoorn, N. and T. Pinch (2003). How users matter: the co-construction of users and technology. Massachusetts, MIT Press.

Oughton, C., M. Landabaso, et al. (2002). "The regional innovatioon paradox: innovation policy and industrial policy." Journal of Technology Transfer 27: 97-110.

Pavitt, K. (1984). "Sectoral patterns of technical change: towards a taxonomy and a theory." Research

Policy(13): $343-373$

Perkmann, M. and A. Spicer (2007). "Healing the Scars of History: Projects, Skills and Field Strategy in Institutional Entrepreneurship." Organization Studies 28(7): 1101-1122.

Pinch, T. J. and W. E. Bijker (1987). The social construction of facts and artifacts: or how the sociology of science and the sociology of technology might benefit each other. The Social Construction of Technological Systems: New Directions in the Sociology and History of Technology. W. E. Bijker, T. P. Hughes and T. J. Pinch. Cambridge, MA, The MIT Press.

Piore, M. and C. Sabel (1982). The second industrial divide. New York, Basic Books. 
Rittel, H. J. and M. M. Webber (1984). Planning problems are wicked problems. Developments in Design

Methodology. N. Cross, Wiley: 135-144.

Ritvala, T. and A. Salmi (2008). Actor mobilization and institutional change around a common issue: the case of

fighting heart disease in Finland. 24th IMP Conference. Uppsala, Sweden.

Rogers, E. M. (2003 [1962]). Diffusion of Innovations. New York; London, Free Press.

Schumpeter, J. A. (1942). Capitalism, Socialism and Democracy. New York, Harper.

Schweber, L. and C. Harty (2010). "Actors and objects: a socio-technical networks approach to technology

uptake in the construction sector." Construction Management and Economics 28(6): 657 - 674.

Scotchmer, S. (2004). Incentives and Innovation, MIT Press.

Scott, R. W. (2001). Institutions and Organizations. Thousand Oaks, CA, Sage Publications.

Sheffer, D. A. and R. E. Levitt (2010). The Diffusion of Energy Saving Technologies in the Building Industry:

Structural Barriers and Possible Solutions. CRGP Working Paper \#57. Stanford University, Center for Research in Global Projects.

Shove, E., M. Watson, et al. (2007). The Design of Everyday Life. Oxford, Berg.

Steen, J. (2010). "Actor-network theory and the dilemma of the resource concept in strategic management " 
Scandinavian Journal of Management 26(3): 324-331.

Steen, J., C. Coopmans, et al. (2006). "SO!APBOX: Structure and agency? Foundation of strategic organization." Strategic Organization 4(3): 303-312.

Strang, D. and S. A. Soule (1998). "Diffusion in Organizations and Social Movements: From Hybrid Corn to

Poison Pills." Annual Review of Sociology 24: 265-290.

Teece, D. J. (1986). "Profiting from technological innovation: implications for integration, collaboration, licensing and public policy." Research Policy 15(6): 285-305.

Tidd, J., J. Bessant, et al. (2005). Managing Innovation. London, Wiley.

Tryggestad, K., S. Georg, et al. (2010). "Constructing buildings and design ambitions." Construction Management and Economics 28(6): 695-705.

Van de Ven, A., D. Polley, et al. (1999). The Innovation Journey. New York, Oxford University Press.

Vermeulen, P., R. Büch, et al. (2007). "The Impact of Governmental Policies in Institutional Fields: The Case of Innovation in the Dutch Concrete Industry." Organization Studies 28(4): 515-540.

Verweij, M., M. Douglas, et al. (2006). The Case for Clumsiness. Clumsy solutions for a complex world: governance, politics and plural perceptions. M. Verweij and M. Thompson. Basingstoke, Palgrave Macmillan. 
von Hippel, E. (2005). Democratizing Innovation. Cambridge, MA, MIT Press.

von Tunzelmann, N. and V. Acha (2005). Innovation in 'Low Tech' Industries. The Oxford Handbook of

Innovation. J. Fagerberg, D. C. Mowery and R. R. Nelson. Oxford, OUP: 407-432.

Wijen, F. and S. M. Ansari (2007). "Overcoming Inaction through Collective Institutional Entrepreneurship:

Insights from Regime Theory." Organization Studies 28(7): 1079-1100. 

Figure 1: classic innovation theory on long waves of technological change (a) adapted from Dodgson, 2000: p. 20; and (b) reproduced from Hargroves and Smith, 2005: p.17 
i The authors thank an anonymous reviewer for highlighting this aspect.

Table 1: Different theories of innovation and the role of stakeholders

Long waves

Firm-level

User

Involvement

Collective

Distributed

Transition

Focus

Technical (technology as new)

Socio-technical (technologies in use)

Unit of

analysis 
Long wave

Firm

Technology

Institutional field

Network

System

Level of

analysis

„Macro.

„Micro.

Meso

Meso

Meso

Meso 
Role of

„stakeholders.

Not specified

External

Intrinsic

Intrinsic

Intrinsic

Intrinsic

Areas of study

. Patents

. R\&D

. General purpose

technologies

. High

technology

„carrier. sectors 


\section{. Resources}

. Capabilities

. Intellectual

property

. Licensing

. Complementary

assets

. Shareholder

value

\section{. Demand}

. Consumption

. Technology

development

. Sources of

innovation

. Institutions

. Power conflicts

. Common ground

. Bandwagons

. Incentives

. Ethical

considerations

. Implementation 


\section{. Networks}

. Actors

. Translation

. Delegation of

interests

. Actor-networks

. Hybrid forms

. Institutional

framework

. Inter-firm

relations

. Learning

capability

. R\&D intensity

. Innovation

activity 

